\title{
Characteristics of Particulate Emissions from Co-Firing in An Industrial Boiler
}

\section{Karakteristik Emisi Partikulat dari Bahan Bakar Co-Firing di Boiler Industri}

\author{
Ines Saraswati Rudianto ${ }^{1}$, Didin Agustian Permadi ${ }^{1 *}$ and Dyah Marganingrum ${ }^{2}$ \\ ${ }^{1}$ Institut Teknologi Nasional, Environmental Engineering, Jl. PH.H. Mustofa No. 23, Bandung, Indonesia, 40124 \\ ${ }^{2}$ Research Center for Geotechnology - Indonesian Institute of Science (LIPI), Jl. Sangkuriang, Bandung, \\ Indonesia, 40135 \\ *E-mail: didin@itenas.ac.id
}

Diterima 4 Januari 2021, direvisi 25 Januari 2021, disetujui 2 Maret 2021

\begin{abstract}
Characteristics of Particulate Emissions from Co-Firing in An Industrial Boiler. PT. X is a textile industry that consumes a massive amount of coal for its boiler operation. It requires substantial costs to obtain coal from Sumatra and Kalimantan. An alternative solid biofuel (briquette) was developed to combine bottom ash and biomass made from municipal solid waste called Biomass Coal Fuel (BCF) briquette. The purpose of this study is to measure the total concentration of particulate matter and emission factor (PM) emitted from two burning experiments: only coal (100\%) and mixed coal fuel with $10 \%$ of BCF (co-firing). Mixed coal and BCF burning are carried out in the fire-tube boiler where the PM emission is released through the stack. The Center for Pulp and Paper measured particulate emission with methodology referring to SNI 7117.17-2009. Particulate matter concentration emitted from only coal-burning was $12,1 \mathrm{mg} / \mathrm{Nm}^{3}$, but when mixed $\mathrm{BCF}$ and coal were used, the higher concentration was emitted $70,9 \mathrm{mg} / \mathrm{Nm}^{3}$. The addition of $\mathrm{BCF}$ briquettes affects the particulate matter emission, even though the emission does not exceed the regulated quality standard. The increase of particulate concentration is due to the $\mathrm{BCF}$ briquette characteristics, which have a low heating value and high ash content. The boiler has already been equipped with cyclone and wet scrubber; therefore, PM emissions presented here are treated emissions. The controlled PM emission factor of BCF was $4,46 \mathrm{~g} / \mathrm{kg}$, which is higher than only coal which was $0,51 \mathrm{~g} / \mathrm{kg}$. BCF briquette can still be used as co-fuel for the boiler, but further effort is still required to reduce the ash content of the $\mathrm{BCF}$ and increase the calorific value of the BCF.
\end{abstract}

Kata kunci: Briquette, bottom ash, coal, industrial boiler, particulate emission.

\section{ABSTRAK}

Karakteristik Emisi Partikulat dari Bahan Bakar Co-Firing di Boiler Industri. PT. X, sebuah industri tekstil, mengonsumsi batu bara sebagai sumber energi untuk pengoperasian boiler dalam jumlah yang cukup besar. Hal tersebut menimbulkan biaya yang cukup besar untuk mendapatkan batu bara dari Sumatera dan Kalimantan. Alternatif bahan bakar yang dapat digunakan untuk menggantikan konsumsi batu bara adalah Briket Biofuel yang terbuat dari gabungan bottom ash dan biomassa yang berasal dari limbah perkotaan, yang disebut sebagai Biomass Coal Fuel (BCF). Tujuan penelitian ini adalah untuk mengukur konsentrasi Total Partikulat yang diemisikan dari pembakaran batu bara dan pembakaran campuran batu bara dengan BCF sebanyak 10\%. Pembakaran bahan bakar tersebut dilakukan di dalam boiler dimana emisi partikulat dilepaskan melalui cerobong. Pengukuran emisi partikulat dilakukan oleh Balai Besar Pulp dan Kertas dengan metodologi mengacu pada SNI 7117.172009. Konsentrasi materi partikulat yang diemisikan dari pembakaran batubara adalah $12,1 \mathrm{mg} / \mathrm{Nm} 3$ tetapi ketika campuran batu bara dan BCF digunakan, konsentrasi emisi meningkat menjadi 70,9 mg/ Nm3. Penambahan briket BCF mempengaruhi emisi bahan partikulat, meskipun emisi yang dikeluarkan tidak melebihi baku mutu yang berlaku. Peningkatan konsentrasi partikulat ini disebabkan karakteristik 
briket BCF yang memiliki nilai kalor rendah dan kadar abu tinggi. Boiler telah dilengkapi dengan cyclone dan wet scrubber sehingga emisi PM yang disajikan di sini merupakan emisi yang diolah. Faktor emisi partikulat dari BCF adalah 4,46 g/kg yang lebih tinggi dari batu bara yang hanya $0,51 \mathrm{~g} /$ kg. BCF masih dapat digunakan sebagai bahan bakar untuk boiler tetapi diperlukan upaya lebih lanjut untuk mengurangi kadar abu BCF dan meningkatkan nilai kalor BCF.

Kata kunci: briket, bottom ash, batu bara, boiler industri, emisi partikulat.

\section{Introduction}

Indonesia holds 26,2 billion tonnes of proven coal reserves as of 2018. Compared to 2017, Indonesia's coal reserves decreased, which initially amounted to 28,4 billion tonnes (Kementrian Energi dan Sumber Daya Mineral, 2018). The textile industry requires a high amount of energy for their boiler operation, which consumes a substantial amount of coal as much as 27 ton/day for two boilers, which boiler 1 (this study) consumes about 7 ton/day and the other consumes about 20 ton/day. The coal is obtained from suppliers who brought them from Sumatra and Kalimantan. Thus, a substantial amount of budget should annually be secured to buy this. There is a need to reduce dependency on using coal as a fuel for boiler operation.

Indonesia has abundant renewable energy sources such as geothermal, hydropower, and biomass. Biomass such as rice husk, coffee husk, coconut shell, and other biomass is widely used as an aggregate of briquette. Briquette is densified biomass fuel commonly used for various purposes to utilize heat energy from combustion, especially in the industry (Bagus Setyawan, 2019). Therefore, the industry uses their available materials for reuse such as bottom ash to be mixed with compost produced from municipal solid waste named Biomass Coal Fuel (BCF) briquette. BCF Briquettes are made from two materials combined with a formulation consisting of $60 \%$ of bottom ash and 40\% biomass. The bottom ash is sourced from coal-burning waste in the same industry in which the study was conducted. In contrast, biomass is derived from municipal solid waste from Bandung City and Saguling reservoir, processed using "peuyeumization" method. Both materials were mixed homogeneously using a binder with starch adhesive as much as $2 \%$ of weight (Marganingrum, 2019).

BCF briquette was burned in the steam boiler mixed with coal as much as $10 \%$, and another experiment was conducted only with coal $(100 \%)$. The addition of BCF briquettes is only given at $10 \%$ so that it does not affect the boiler's work, which was originally used with only coal (Marganingrum, 2019).

During the biomass briquette burning, particulate matter (PM) emissions are generally dominated by sub-micrometre particle which can cause severe health effects such as lung cancer to heart disease (Simões Amaral, Andrade de Carvalho, Martins Costa, \& Pinheiro, 2016).

The negative impact of this emission from combustion can affect using biomass briquettes as alternative energy. The purpose of this study was to measure the total concentration of particulate from coal fuel mixed with BCF briquette as much as $10 \%$ combustion as compared to solely coal fuel combustion (100\%). This study's benefits are to show the effect of BCF briquettes substitution related to particulate emissions and provide recommendations to reduce particulate emissions.

\section{Methods}

The measurement of total particulate concentration for this study was carried out 
directly on the stack of the Textile Industry located in Bandung Regency, West Java by Center for Pulp and Paper (Balai Besar Pulp dan Kertas / BBPK) for 1 hour, referring to the requirements of Indonesia National Standard (SNI) 7117.13-2009 to 7117.172009.

Experiments were conducted with $100 \%$ of coal (control experiment) and the mixture of coal with $10 \% \mathrm{BCF}$ (by mass). The amount of fuel that was combusted by each boiler in the industry is shown in Table 1.

Table 1. Total Usage of Fuel for Two Experiments

\begin{tabular}{cccc}
\hline \multirow{2}{*}{ Boiler } & \multicolumn{3}{c}{$\begin{array}{c}\text { Fuel Consumption } \\
\text { (ton/day) }\end{array}$} \\
\cline { 2 - 4 } & BCF & Coal & Total \\
\hline $\begin{array}{c}\text { Experiment I: } \\
\text { Boiler I (Fire Tubes) }\end{array}$ & 0,7 & 6,3 & 7 \\
$\begin{array}{c}\text { Experiment II: } \\
\text { Boiler I (Fire Tubes) }\end{array}$ & - & 7 & 7 \\
\hline
\end{tabular}

Source: Indonesian Institute of Science (LIPI), 2020

The measurement of total particulate concentration is taken on different days. Experiment I was carried out on March $9^{\text {th }}, 2020$, and experiment II on February $26^{\text {th }}, 2020$. Based on the SNI method, the particulate test sample was taken isokinetically. Isokinetic is a condition where the sampling line's flow rate should be equal to or close to the gas flow velocity at the stack's sampling point. The crossing points, linear velocity, exhaust gas composition, exhaust gas content in the stack must be determined in advance. The linear velocity of the exhaust gas sucked through the nozzle is equal to the exhaust gas's linear velocity in the stack. (Badan Standarisasi Nasional, 2009)

Theoretically, the required number of crossing points on the industry's stack should be 12 for two test-sampling holes, but the number of sampling points used was only half of the crossing points. We considered the isokinetic condition during sampling, which was carefully tested. The equipment used for measurement includes nozzles, pumps, barometer, and filter. The equipment can be seen in Figure 1.

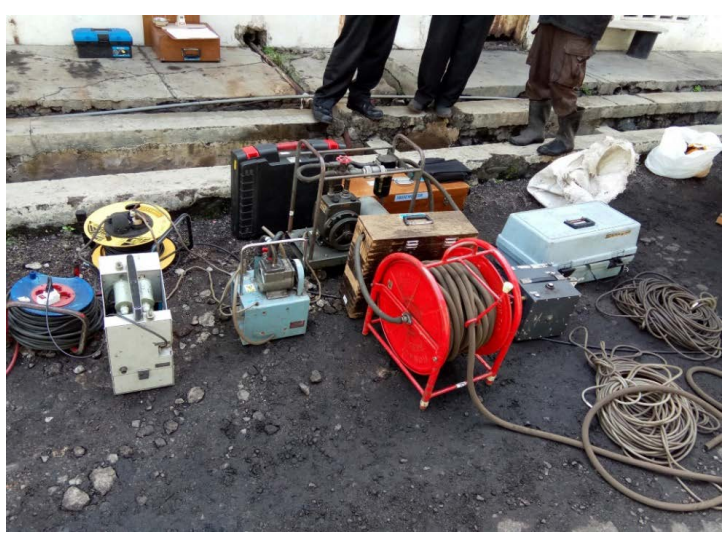

Figure 1. Particulate Emission Measurement Equipment

The isokinetic sampling at the industry was preliminarily tested using a wet gas flow meter and pump. Before that, the exhaust gas was pumped into the wet gas flow meter with filters with several stages. The first filter was an ordinary dust filter, while the second stage was prepared by dissolving 5\% hydrogen peroxide liquid in water which served to keep the pump from being damaged by the dust. If there were corrosive gas emitted, the gas would be dissolved in a hydrogen peroxide solution. Then the gas would be flown to the wet gas flow meter to reach a linear velocity of 50 litres per minute as one of the requirements for the isokinetic condition. The wet gas flow meter is equipped with a manometer for measuring gas pressure and an orifice for measuring exhaust gas's temperature. Once the isokinetic condition was met, a particulate emission test could be performed. The steps for the particulate test was following SNI 7117.17-2009 as described as follows:

1. Position the particulate test sample set in the sample test hole;

2. Turn on the heater filter and probe at a temperature of $120^{\circ} \mathrm{C} \pm 4^{\circ} \mathrm{C}$;

3. Place the nozzle tip at the first point of the passage with the inlet facing the gas flow; 
4. Start the pump with the suction speed according to the isokinetic speed;

5. Maintain the isokinetic rate at $100 \% \pm$ $10 \%$ by adjusting the pressure of the suction pump rate $(\mathrm{dH})$ valve according to the ratio $\mathrm{K}$ to the pitot tube pressure difference, and also maintain the filter temperature at $120^{\circ} \mathrm{C} \pm 4^{\circ} \mathrm{C}$ during sampling and record all measured data;

6. After sampling the test sample at the first crossing point, move the nozzle to the next crossing point and repeat the abovementioned steps up to the last crossing point.

7. Once the test is completed, turn off the suction pump, remove the probe and nozzle from the sampling hole.

The filters used to capture particulates in the stack were dried in an oven at a temperature of $105 \mathrm{oC}$ for 2 hours to 3 hours, then cooled in a desiccator. After that, the filter is weighed using analytical scales in the laboratory. The type of boiler used in the study site was a fire tube boiler. The boiler can be fueled by coal or briquette. The boiler is connected to stack B1 for the discharge of flue gas emissions. The boiler fuel was supplied by a manual hand stoker and was equipped with particulate removal devices such as the cyclone precipitator and wet scrubber.

The particulate emission measurement results were analyzed by comparing the particulate emissions from experiments I and II. They then analysed the effect of the characteristics of the BCF briquette and coal, and also the emission factors of $\mathrm{BCF}$ briquettes and coal-based on various literature.

\section{Result and Discussion}

\section{1. Concentration of Particulate Emission}

The particulate emission test aims to measure the particulate level released from the combustion process using BCF briquette. The value of particulate emissions resulting from this study is shown in Table 2 .

The value of the particulate concentration in the stack increased significantly with the addition of $\mathrm{BCF}$ briquettes to coal. The fuel combustion with $100 \%$ coal would emit PM of approximately $12,1 \mathrm{mg} / \mathrm{Nm}^{3}$, but when $10 \%$ of the fuel were substituted with $\mathrm{BCF}$, the PM emission increased to $70,9 \mathrm{mg} / \mathrm{Nm}^{3}$.

However, the results are far lower than the PM emission standard regulated in the Minister of Environment Regulation No. 7 of 2007, which requires that the quality of particulate emission for coal combustion to be lower than $230 \mathrm{mg} / \mathrm{Nm}^{3}$ and for coal with $\mathrm{BCF}$ briquette combustion to be lower than $278 \mathrm{mg} / \mathrm{Nm}^{3}$. This may be due to the use of cyclones and wet scrubbers. Combustion of coal and BCF briquettes containing biomass produces particulate emissions in fly ash and organic matter due to the evaporation of volatile material (Niu \& Tan, 2016).

The fuel characteristics of coal and BCF were compared, and the result is presented in Table 3. Note that BCF has a lower calorific value and much higher ash content than coal. Therefore this could contribute to higher PM emission measured at the stack. The particulate emission is influenced by heating value. The higher the calorific value, the

Table 2. Particulate Emissions

\begin{tabular}{ccc}
\hline Combustion Fuel & $\begin{array}{c}\text { Particulate emission (mg/ } \\
\left.\mathbf{N m}^{3}\right)\end{array}$ & $\begin{array}{c}\text { Quality Standard for } \\
\text { Particulate Emission }\left(\mathbf{m g} / \mathbf{N m}^{\mathbf{3}}\right)\end{array}$ \\
\hline Coal (February $26^{\text {th }}$ 2020) & $12,1^{1)}$ & $230^{2)}$ \\
\hline $\begin{array}{c}\text { Coal + 10\% BCF Briquette } \\
\left(\text { March } 9^{\text {th }} \text { 2020) }\right.\end{array}$ & $70,9^{1)}$ & $278^{2)}$ \\
\hline
\end{tabular}

Source: ${ }^{1)}$ Center for Pulp and Paper, 2020

2) Regulation of The Minister of Environment No.7, 2007 
Table 3. Characteristics of Coal and BCF Briquette

\begin{tabular}{cccccc}
\hline Sample & $\begin{array}{c}\text { Moisture } \\
\text { Content (\%) }\end{array}$ & $\begin{array}{c}\text { Ash Content } \\
\mathbf{( \% )}\end{array}$ & $\begin{array}{c}\text { Calorific value } \\
\text { (calorie/g) }\end{array}$ & $\begin{array}{c}\text { Volatile } \\
\text { matter (\%) }\end{array}$ & $\begin{array}{c}\text { Fixed } \\
\text { Carbon (\%) }\end{array}$ \\
\hline $\begin{array}{c}\text { Coal } \\
\text { Coal with 10\% } \\
\text { of BCF }\end{array}$ & 23,15 & 2,65 & 5223 & 36,99 & 37,13 \\
\hline
\end{tabular}

Source: Indonesian Institute of Science (LIPI), 2020

lower the resulting emission value because the fuel is easier to burn, and combustion efficiency will be higher (Miharja, 2018).

The high calorific value of briquettes results in complete combustion. In contrast, the coal with $10 \%$ of $\mathrm{BCF}$ briquette has a calorific value of 4951 calorie/g, which is a low calorific value so that it affects particulate emissions. The low calorific value is caused by the ash content's high value (Rahmadani, Hamzah, \& Hamzah, 2017). A significant portion of BCF was from bottom ash, which is the residue of coal combustion and has bigger and heavier particles than fly ash.

The value of ash content in the coal with $10 \%$ of $\mathrm{BCF}$ briquette is $7,69 \%$. BCF briquette products were made from bottom ash taken from coal combustion as much as $40 \%$ and mixed compost waste of around $60 \%$. Bottom ash has a high ash content with a low calorific value, affecting the boiler's combustion efficiency to be lower than coal. The briquette was not burned completely, which caused the formation of $\mathrm{CO}$, smoke, and dust.

We also compared the particulate emission from another research using biomass and coal combustion, which is called co-firing. According to Al-Naiema et al (2015), co-firing with $50 \%$ of oat hulls significantly reduced $90 \%$ of the particulate emission.

Research by Chang et al (2019) reports no significant difference in particulate emission when adding biomass and coal. For coal combustion, PM concentration was $0,61 \mathrm{mg} / \mathrm{Nm}^{3}$, and after biomass was added, the particulate emission was $0,47-0,95 \mathrm{mg} /$ $\mathrm{Nm}^{3}$. It can be concluded that particulate emissions with co-firing could be varied depending on the biomass material used.

\subsection{Emission Factors}

The emission factors are the average value of air pollutant parameters released from a specific source, and they can differ from one another for each parameter (Handriyono \& Kusuma, 2017). Particulate emission factors from coal combustion and coal + BCF combustion were calculated using emission concentration, debit, fuel consumption, and measurement time. Data were also compared with emission factors from Atmospheric Brown Clouds Emission Inventory Manual (ABC EIM) to calculate coal emission factor, which only uses data of ash content. The information on particulate emission factors is essential for developing pollution control strategies (Simões Amaral et al., 2016).

The particulate emission factor calculation results show that the additional $10 \%$ of BCF has the highest value of $4,46 \mathrm{~g} /$ $\mathrm{kg}$. This is due to the value of the particulate concentration and debit values resulting from coal combustion with BCF higher than combustion with coal only. We compared the emission factor from ABC EIM where the particulate emission for coal fuel with lignite type is $3,98 \mathrm{~g} / \mathrm{kg}$.

Figure 2 shows that every coal burned weight will produce a smaller amount of particulate concentration compared to the literature from ABC EIM. Furthermore, 


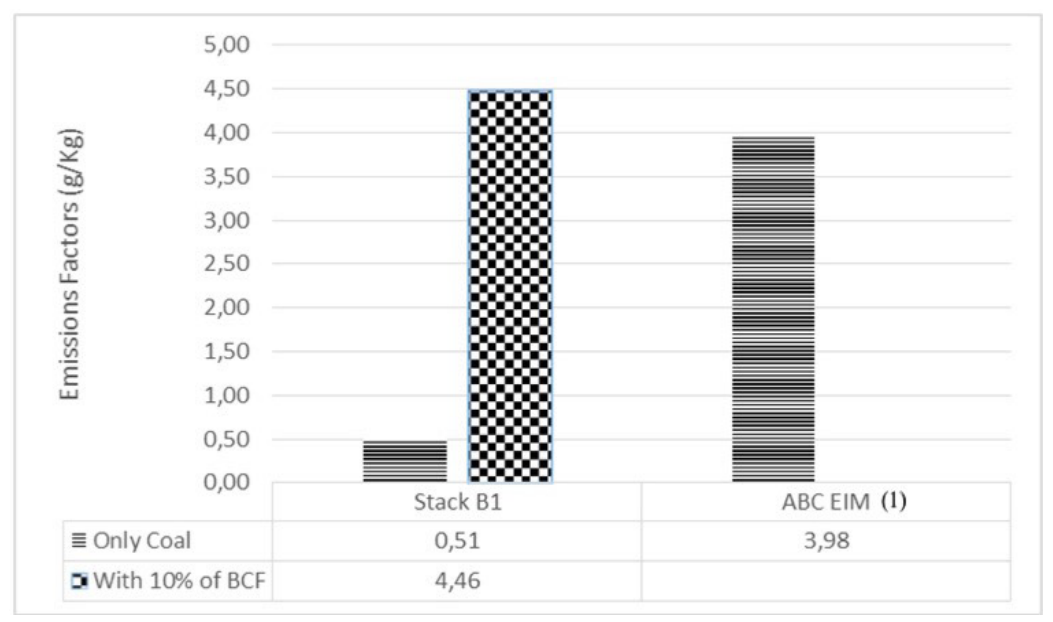

Figure 2. Particulate Emission Factors

Source: (1) Shrestha, R. M., et al, 2013

every addition of briquettes burned will produce a larger amount of particulate concentration than coal and the literature from ABC EIM. Moreover, compared with the particulate emission factor from other biomass energy such as rice straw and crop residue, it was carried out as shown in Table 4.

Table 4. Particulate Emission Factor from Other Biomass Energy

\begin{tabular}{clc}
\hline No & \multicolumn{1}{c}{ Fuel } & $\begin{array}{c}\text { Emission Factor } \\
\mathbf{( g / K g )}\end{array}$ \\
\hline 1 & Coal (this study) & 0,51 \\
2 & A briquette & 4,46 \\
3 & (this study) $^{\text {Rice Straw }}$ & 4,7 \\
4 & Crop residue $^{1)}$ & 7,54 \\
\hline
\end{tabular}

Source: ${ }^{1)}$ Simoes Amaral et al, 2016

Table 4 shows that the particulate emission resulting from the agricultural residues and bagasse are greater than the particulates resulting from burning $\mathrm{BCF}$ briquettes. It depends on the combustion technology used.

\section{Conclusion}

The addition of BCF briquette in coal fuel increased particulate matter emissions to $71,9 \mathrm{mg} / \mathrm{Nm}^{3}$ and was still below the standard. Factors that influence the high value of particulate emissions are low heating value and high ash content, which affect the boiler's combustion efficiency.

The controlled PM emission factor of $\mathrm{BCF}$ was $4,46 \mathrm{~g} / \mathrm{kg}$, which is higher than $100 \%$ coal of $0,51 \mathrm{~g} / \mathrm{kg}$. By now, BCF briquette can still be used as co-fuel for the boiler as the emissions were still lower than the standard, but there is a need to lower down its emission. Further effort should be done to decrease the ash content of the BCF and increase the calorific value of the $\mathrm{BCF}$..

\section{Acknowledgement}

We acknowledge to Research Center for Geotechnology, Indonesian Institute of Sciences (LIPI), that supports technical and financial assistances to the authors to conduct this study.

\section{Authorship}

In this study, the first author contributed to the data collection and data processing and provided the manuscript's draft. Other co-authors contributed to the refinement of the manuscript. 


\section{References}

Al-Naiema, I., Estillore, A. D., Mudunkotuwa, I. A., Grassian, V. H., \& Stone, E. A. (2015). Impacts of co-firing biomass on emissions of particulate matter to the atmosphere. Fuel, 162, 111-120.

Badan Standarisasi Nasional. (2009). SNI 7117.17-2009 tentang Penentuan Konsentrasi Partikulat dalam Gas Buang. Jakarta: Badan Standarisasi Nasional.

Bagus Setyawan, S. (2019). Analisis mutu briket arang dari limbah biomassa campuran kulit kopi dan tempurung kelapa dengan perekat tepung tapioka. Edubiotik: Jurnal Pendidikan, Biologi dan Terapan, 4(2).

Center for Pulp and Paper. (2020). Result of test (Laporan Hasil Uji). Retrieved from Bandung:

Chang, C.-C., Chen, Y.-H., Chang, W.-R., Wu, C.-H., Chen, Y.-H., Chang, C.-Y., . . . Chiang, S.-W. (2019). The emissions from co-firing of biomass and torrefied biomass with coal in a chain-grate steam boiler. Journal of the Air \& Waste Management Association, 69(12), 1467-1478.

Handriyono, R., \& Kusuma, M. N. (2017). Estimasi beban emisi $\mathrm{SO}_{2}$ dan $\mathrm{NO}_{x}$ dari kegiatan industri di Karang Pilang Surabaya. Paper presented at the Seminar Nasional Sains dan Teknologi Terapan V.

Indonesian Institute of Science (LIPI). (2020a). Characteristics of Coal and BCF Briquette. Retrieved from Bandung:

Indonesian Institute of Science (LIPI). (2020b). Total Usage of Fuel in PT.X, The Textile Industry. Retrieved from Bandung:

Kementrian Energi dan Sumber Daya Mineral. (2018). Cadangan Batu Bara Indonesia Sebesar 26 Miliar Ton.

Marganingrum, D., Lenny Marilyn Estiaty, Chandra Irawan, Hidawati. (2019). The Biomass Coal Fermented (BCF) Briquette as an Alternative Fuel. MSCEIS. doi:10.4108/eai.12-10-2019.2296375.

Miharja, M. H. J. (2018). Analisis Proksimat Potensi Briket Bioarang sebagai Energi Alternatif di Desa Kusu, Maluku Utara. Techno: Jurnal Penelitian, 5(1), 15-21.
Niu, Y., \& Tan, H. (2016). Ash-related issues during biomass combustion: Alkaliinduced slagging, silicate melt-induced slagging (ash fusion), agglomeration, corrosion, ash utilization, and related countermeasures. Progress in Energy and Combustion Science, 52, 1-61.

Peraturan Menteri Lingkungan Hidup. (2007). Peratuan Menteri Lingkungan Hidup No 7 Tahun 2007 tentang Baku Mutu Emisi Tidak Bergerak Bagi Ketel Uap.

Rahmadani, R., Hamzah, F., \& Hamzah, F. H. (2017). Pembuatan briket arang daun Kelapa sawit (Elaeis guineensis jacq.) dengan perekat pati sagu (Metroxylon sago rott.). Riau University.

Shrestha, R. M., Kim Oanh, N., Shrestha, R., Rupakheti, M., Rajbhandari, S., Permadi, D., . . Iyngararasan, M. (2013). Atmospheric Brown Clouds: Emission Inventory Manual.

Simões Amaral, S., Andrade de Carvalho, J., Martins Costa, M. A., \& Pinheiro, C. (2016). Particulate matter emission factors for biomass combustion. Atmosphere, 7(11), 141. 